\title{
Pathological studies and detection of co-infection of bovine papilloma viruses in cattle cutaneous and teat warts
}

\author{
Babu L. Jangir, and Ramesh Somvanshi* \\ Division of Pathology, ICAR-Indian Veterinary Research Institute, Izatnagar, Uttar Pradesh, India
}

JANGIR, B. L., R. SOMVANSHI: Pathological studies and detection of co-infection of bovine papilloma viruses in cattle cutaneous and teat warts. Vet. arhiv 91, 589-602, 2021.

\section{ABSTRACT}

Bovine papillomas are benign tumors of the cutaneous and mucosal epithelia and are commonly found in cattle. The productivity loss and economic impact depends on the location and degree of infection. The present study was undertaken to investigate the pathology and association of different bovine papilloma virus (BPV) types in cattle cutaneous and teat warts. Grossly, the warts were of variable size and shape (rice grain, cauliflower and fingerlike horny growths or irregular). Histopathologically, the warts were diagnosed as fibropapilloma, papilloma, fibrosarcoma and hyperplasia. Fibropapilloma was the most frequent histological type observed and was characterized by hyperkeratosis, parakeratosis and acanthosis. PCR revealed the presence of either BPV-1, -2 and -5 DNA or their co-infections. Transmission electron microscopy on negative staining showed BPV-like particles. Varied copy numbers of viral DNA of BPV-1, -2 and -5 were detected by real-time PCR. Immunohistochemistry revealed the expression of Ki-67 mainly in the proliferating cells of stratum spinosum and a few basal cells in papilloma and fibropapilloma. Cyclooxygenase-2 immunostaining was observed in the cytoplasm and cell membrane of suprabasal cells. In conclusion, cutaneous and teat warts in cattle in India are more frequently associated with BPV-1/ -2 and their mixed infections, with the rare presence of BPV-5. The DNA of BPV-5 was detected for the first time in warts in India. Co-infection with two or three different viral types demonstrated the diversity of BPV types involved in warts. The frequent expression of Ki-67 in suprabasal layers may be indicative of its association with viral replication and that they are as proliferation sites.

Key words: bovine papilloma virus; cattle; cutaneous warts; Ki-67; teat warts

\section{Introduction}

Bovine papillomas are benign tumors of the cutaneous and mucosal epithelia, and are commonly found in cattle. They are characterized by variably sized warts located on the skin, localized on the teats, or generalized to the mucosa of the upper alimentary tract. They cause deterioration of the appearance of the skin and the economic depreciation of animals (JUBB et al., 2016). Under the influence of environmental co-factors, bovine papilloma viruses (BPVs) induce lesions in cattle and may progress to cancer (CAMPO, 2006). BPVs are small (55 $\mathrm{nm}$ in diameter), non-enveloped and icosahedral in shape. The replication site of these viruses is the nuclei of squamous epithelial

\footnotetext{
*Corresponding author:

ICAR-Emeritus Prof. Ramesh Somvanshi, Division of Pathology, ICAR-Indian Veterinary Research Institute, Izatnagar 243 122, Uttar Pradesh, India, E-mail: dr.rsomvanshi@gmail.com
} 
cells (HOWLEY et al., 2013). Hundreds of human papillomavirus (HPV) types have been described, however, only twenty-eight (28) BPV types have been characterized so far (RUSSO et al., 2020).

BPVs are distributed in cattle herds throughout the world. BPVs cause cutaneous fibropapillomas, genital fibromas, urinary bladder tumors, and benign fibroplasia in the oesophagus and teats. BPV-1 or BPV-10 or their mixed infections have been reported in teat warts (TWs) in Indian cattle (KUMAR et al., 2013a). However, in cutaneous warts (CWs) of cattle and buffaloes, BPV-1 or BPV2 or their mixed infections have been reported from India (PANGTY et al., 2010; KUMAR et al., 2013b). Mixed infections of BPVs have been reported in CWs and TWs in different countries of the world, e.g. Japan, Brazil and Germany (OGAWA et al., 2004; CLAUS et al., 2009; SCHMITT et al., 2010; SILVA et al., 2010; CARVALHO et al., 2012).

The proliferation of squamous cells in the skin or mucosal regions is a characteristic feature of papillomatosis. Various markers are expressed during cell division with each having a specific function. The Ki-67 nuclear antigen is the most reliable indicator of cellular proliferation. It is expressed in all phases of the cell-cycle, except $\mathrm{G}_{0}$ (LU et al., 1999). The expression of Ki-67 in relation to HPV revealed that $\mathrm{Ki}-67$ is expressed in the infected epithelial layers (DOORBAR et al., 2012). Expression of cyclooxygenase- 2 (COX2) has been reported in several different types of cancers in both humans and animals (DORE et al., 2003). However, scant information is available on COX-2 expression in cutaneous papilloma and fibropapilloma cases in cattle and buffaloes.

Recent studies in BPV biology suggested the great diversity of BPV types, their co-infections in cattle herds from various parts of the world, and new putative BPV types. BPVs are not site-specific and their mixed infections have been reported in cutaneous and mucosal warts of cattle and buffaloes from different parts of the world. With this in mind, the present investigation was designed to study the pathomorphology and involvement of different BPV types in wart-like lesions/growths, and immunohistochemical expression of Ki-67 and COX-2.

\section{Materials and methods}

Collection and preservation of samples. Warts tumor biopsies from cattle were collected from various organized dairy farms in Uttar Pradesh (UP) and Uttarakhand, at the Referral Veterinary Polyclinic of ICAR-Indian Veterinary Research Institute Izatnagar, State Veterinary Hospitals, in different villages around Bareilly, UP and West Bengal. After the administration of local anaesthesia around the growth, biopsy samples were collected and fixed in $10 \%$ neutral buffered formalin for histopathology and immunohistochemistry. A part of the samples with gross lesions were also stored in sterile vials at $-20{ }^{\circ} \mathrm{C}$ for molecular studies and $2.5 \%$ glutraldehyde for transmission electron microscopy.

Pathomorphological studies. The detailed gross findings with the specific location of the wart-like lesions/ growths were recorded. After appropriate fixation, tissues samples were processed routinely for histopathological study by the conventional procedure (LUNA, 1968).

Ultrastructural studies. BPV was purified from natural cases of warts in cattle as per a method described earlier with slight modifications (LANCASTER and OLSON, 1978). Purified virus suspensions were preserved in chilled $2.5 \%$ gluteraldehyde in phosphate buffer $(0.2 \mathrm{M}, \mathrm{pH} 7.4)$ and kept at $4{ }^{\circ} \mathrm{C}$. The clear sample was then applied to a coated TEM grid. A drop of the suspension was put on parafilm and a formvar-carbon coated $400 \mathrm{~m}$ grid was kept over it (film side down) for at least 1 minute (min). After removal of the grid, the excess liquid was drained-off by touching the edge to a piece of clean filter paper. The grid was placed over a drop of $2 \%$ phosphotungstic acid (PTA) stock as above (film side down), the excess fluid was drained-off and it was allowed to dry for a few minutes and examined at the Electron Microscope Facility (Morgagni-268 and Philips CM-10, Holland), Department of Anatomy, All India Institute of Medical Sciences, New Delhi.

DNA extraction and primers. The DNA was extracted from tissue samples using a DNeasy Blood and Tissue Kit (Qiagen, Hilden, Germany) following the manufacturer's instructions. 
Published primers were used to amplify the L1 major capsid protein gene of BPV-1 and -2 (YAGUIU et al., 2006). Specific primers for L1/L2 genes were designed using DNASTAR software from published sequences and commercially synthesized (Operon Biotechnologies, Genetix Biotec). The following were the primers of the

BPV-5, L1 gene

(forward 5'-ACTGGCTCTACCAAGCTCAAGG-3', reverse 5'-GACAGAAGGGTTAACGGTCTGCA-3');

BPV-5, L2 gene

(forward 5'-GGCAGTACACAAGCTAGGCCA-3', reverse 5'-TGCAGGATTCACATCCAAAACAGC-3') and $\mathrm{BPV}-10$

(forward5'-TGCATTCAATAGGCTTGCAGATGC-3', reverse 5'-CACCTCGAGACCACAAATGC-3').

Specific viral DNA template of sizes 301, 164, 266, 360 and 422bp of BPV-1 (L1 gene), BPV-2 (L1 gene), BPV-5 (L1 gene), BPV-5 (L2 gene) and BPV-10 (L1 gene), respectively were expected to be amplified by these primers.

$P C R$ and sequencing. The thermal profile for PCR reaction was comprised of the following steps: initial denaturation step at $94{ }^{\circ} \mathrm{C}$ for $3 \mathrm{~min}$, followed by step 2 comprised of 35 cycles of denaturation for 40 seconds $(\mathrm{sec})$ at $94{ }^{\circ} \mathrm{C}$, annealing for 40 sec at $52{ }^{\circ} \mathrm{C}$ (BPV-1 and -2), $62{ }^{\circ} \mathrm{C}$ (BPV-5) and $60{ }^{\circ} \mathrm{C}$ (BPV-10) with an extension at $72{ }^{\circ} \mathrm{C}$ for 50 sec and finally step 3 consisting of a single cycle of final extension at $72{ }^{\circ} \mathrm{C}$ for $10 \mathrm{~min}$. Amplified DNA fragments were viewed in $1.5 \%$ agarose containing ethidium bromide $(0.5 \mathrm{~g} / \mathrm{mL})$ under UV light (Geldoc; Alpha Tech, San Leandro, CA, USA). A few selective PCR products were directly sequenced commercially on an ABI-PRISM dye terminator of the DNA Sequencing Facility at the Division of Biochemistry, Delhi University, South Campus, New Delhi. This was performed using specific primers, EDITSEQ and MegAlign modules of LASERGENE software (DNASTAR). The sequences generated in this study were aligned by clustal method with the published sequences of different BPVs, and compared and submitted to GenBank.

Real-time PCR. The real-time PCR assay was performed in a Stratagene Mx-3000P real-time
PCR cycler using commercial reagents as per the manufacturer's instructions. The reaction mixture was comprised of $25 \mu \mathrm{L}$ of Eva Green PCR Master mix, $0.6 \mu \mathrm{L}$ each of forward and reverse primers, 3.0 $\mu \mathrm{L}$ DNA and nuclease-free water to make a total reaction volume of $50 \mu \mathrm{L}$. The thermal profile for BPV-1 was comprised of three segments. Segment 1; initial denaturation for $10 \mathrm{~min}$ at $95^{\circ} \mathrm{C}$, followed by segment 2 comprised of 40 repetitive cycles of denaturation for $10 \mathrm{sec}$ at $94{ }^{\circ} \mathrm{C}$, annealing for $25 \mathrm{sec}$ at $55^{\circ} \mathrm{C}$ and extension for $30 \mathrm{sec}$ at $72{ }^{\circ} \mathrm{C}$ each. In segment 3 , dissociation curve analysis was performed comprised of a single cycle of denaturation for $1 \mathrm{~min}$ at $95^{\circ} \mathrm{C}$, partial renaturation to $65{ }^{\circ} \mathrm{C}$ for $30 \mathrm{sec}$ and denaturation again for 30 $\mathrm{sec}$ at $95^{\circ} \mathrm{C}$. For BPV-2 and -5 , the thermal profile was comprised of three similar segments but annealing was carried out at $60^{\circ} \mathrm{C}$ and $63{ }^{\circ} \mathrm{C}$ for 30 and $20 \mathrm{sec}$, respectively for BPV-2 and -5 . For copy number estimation, 10-fold serial dilutions of the known positive control samples were made and the standard curve was then obtained by using dilutions from $10^{-3}$ to $10^{-8}$. Thereafter, the copy numbers of viral DNA were determined from the standard curve.

Immunohistochemistry. Immunohistochemistry was performed on $4 \mu \mathrm{m}$ thick sections mounted on 3 aminopropyl-triethoxysilane (APES) coated slides (Sigma Chemicals, USA). The immunohistochemistry for Ki-67 was performed by a similar procedure as described by KUMAR et al. (2015) with minor modifications, and for COX2 using the protocol as per Santa Cruz Biotech. Antigen retrieval was performed by the microwave oven method in citrate buffer (0.01M, pH 6.0) for 10 min ( 2 cycles of $5 \mathrm{~min}$ ). Quenching of endogenous peroxidase activity was carried out by dipping in 3\% hydrogen peroxide in methanol for $30 \mathrm{~min}$. Primary antibodies (mouse monoclonal anti-Ki67, mAb PP-67, P6834, Sigma-Aldrich and goat polyclonal anti-COX-2 IgG antibody, SC-1746; Santa Cruz Biotech) were used at 1:50 dilution. Secondary antibodies and peroxidases were applied according to the manufacturer's instructions (Sigma for Ki-67 and Santa Cruz Biotech for COX-2). The primary antibody was omitted in the negative control slides but the rest of the procedure was similar. Color 
reactions were developed with 3-amino-9-ethylcarbazole (AEC; Sigma Chemicals, USA) for 3-5 min and counter-stained with Mayer's hematoxylin (Sigma, MHS-16). For estimation of the Ki-67 index, the entire section was screened to find the hot spot area with the maximum number of positively stained nuclei in one microscopic field (40× objective). Then, the fraction of positively stained nuclei was calculated and this was defined as $\mathrm{Ki}$ 67 max (Ki-67 max=Number of nuclei positive for Ki-67 divided by the total number of nuclei in the selected field). The estimation of Ki-67 tot was based on assessment of the immunopositive cells in 5-10 microscopic fields by counting approximately 1000 cells $(\mathrm{Ki}-67$ tot $=$ Number of nuclei positive for Ki-67 divided by the total number of nuclei in all the fields used for counting). Then, the Ki-67 labelling index was expressed as a percentage. The COX-2 immunostaining was determined as per the procedure described by DORE et al. (2003).

\section{Results}

Pathological study. A total of 29 cases (23 CWs and $6 \mathrm{TWs}$ ) were recorded and a detailed account is presented in Tables 1 and 2. Grossly, the CWs were of variable sizes and shape, that is, round pin-head sized, finger-like horny processes, cauliflower-like growths, elevated dome-shaped growths attached to the skin with a broad base, and rough and irregular (Figs. 1A, 1B). In one case, a number of round growths were present on the ventral surface of the tail, a very large irregularly round growth on an udder so that it resembled a scrotum (Fig. 1C), and a few small projecting growths were present over the skin of the forelimbs and hindlimbs. TWs were mostly rice grain-like, but some were sessile, small elevated grayish and usually multiple in number. In one case, numerous small round growths were seen. Some of these growths were coalesced together to form grape-like clusters, while a few other growths had pointed tips and broad bases projecting out from the surfaces (Fig. 1D).

A total of $15 \mathrm{CW}$ and $5 \mathrm{TW}$ samples were subjected to histopathological examination. In the remaining cases, a sufficient amount of sample was not available for histopathological processing. In these cases, the wart-like lesions were tiny and were present in very close associations with skin (e.g. Fig. 1A). CWs were diagnosed as fibropapilloma $(10 / 15)$, papilloma $(2 / 15)$, hyperplasia $(2 / 15)$ and fibrosarcoma (1/15), while TWs as fibropapilloma (4/5) and papilloma (1/5). Histopathologically, fibropapillomas were characterized by hyperkeratosis with a basket weave appearance and parakeratosis. They showed marked acanthosis with thickened stratum spinosum. Long irregular variable-sized rete pegs projecting deep into the proliferating fibrous connective tissue with lateral interconnections were noticed (Fig. 2A). Marked epidermal hyperplasia were noticed with thickening of the stratum granulosum, with the presence of numerous basophilic keratohyaline granules in the cytoplasm (Fig. 2B). In the stratum spinosum and granulosum, numerous koilocytes were observed with condensed hyperchromatic nuclei (centrally, eccentrically placed or crescent shaped). The basal cell layer revealed hyperplasia with the presence of hyperchromatic nuclei and moderate mitotic activity. Microscopically, papilloma revealed epidermal hyperplasia with well developed papillae and excessive proliferation of the overlying stratum corneum, exhibiting orthokeratotic or parakeratotic hyperkeratosis. Hyperplasia cases were characterized by mild to moderate cornification and thickening of the stratum spinosum. Fibrosarcoma revealed excessive proliferation of fibrous tissue with variable sized fibrocytes and fibroblasts, with the pleomorphic nuclei arranged in different directions (Fig. 2C). A few mitotic figures were also present. In some areas, eosinophilic mature collagen fibres were arranged haphazardly, while in other areas they showed a whirling pattern. Angiogenesis was also revealed, with newly formed delicate blood vessels. Fibropapilloma and papilloma cases of TWs revealed similar histopathological findings to the CWs (Fig. 2D).

Transmission electron microscopy (Negative staining). Purified virus suspensions of cutaneous warts of cattle showed BPV-like particles of 48.02$54.62 \mathrm{~nm}$ in size with icosahedral symmetry (Figs. 3A, 3B).

PCR analysis and sequencing. The detailed results of PCR assay are depicted in Tables 1 and 2. 


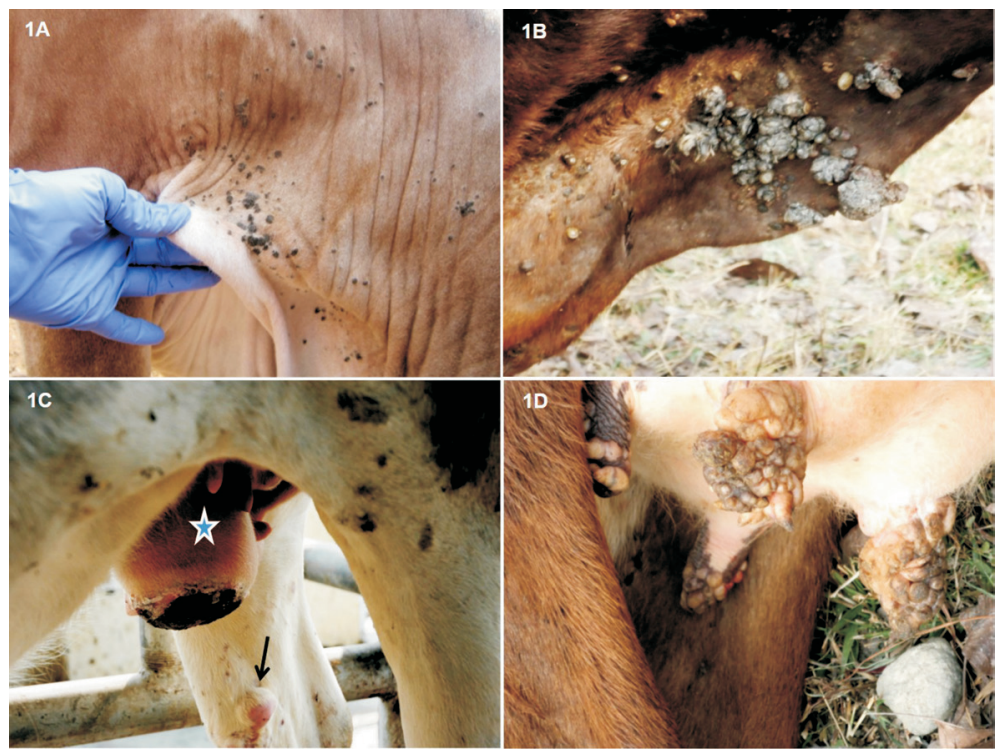

Fig. 1A - Small round, pinhead sized warts on shoulder region (Case No. CW-7)

Fig. 1B - Extensive grayish finger-like horny growths protruding on the neck and dewlap (Case No. CW-1) Fig. 1C - Large size round growth on the udder giving it the resemblance of a scrotum and a small round growth on the inner aspect of the right hind limb (Case No. CW-2). Fig. 1D - Numerous small sized round growths, coalesced together to form grape-like clusters covering the whole teat (Case No. TW-1)

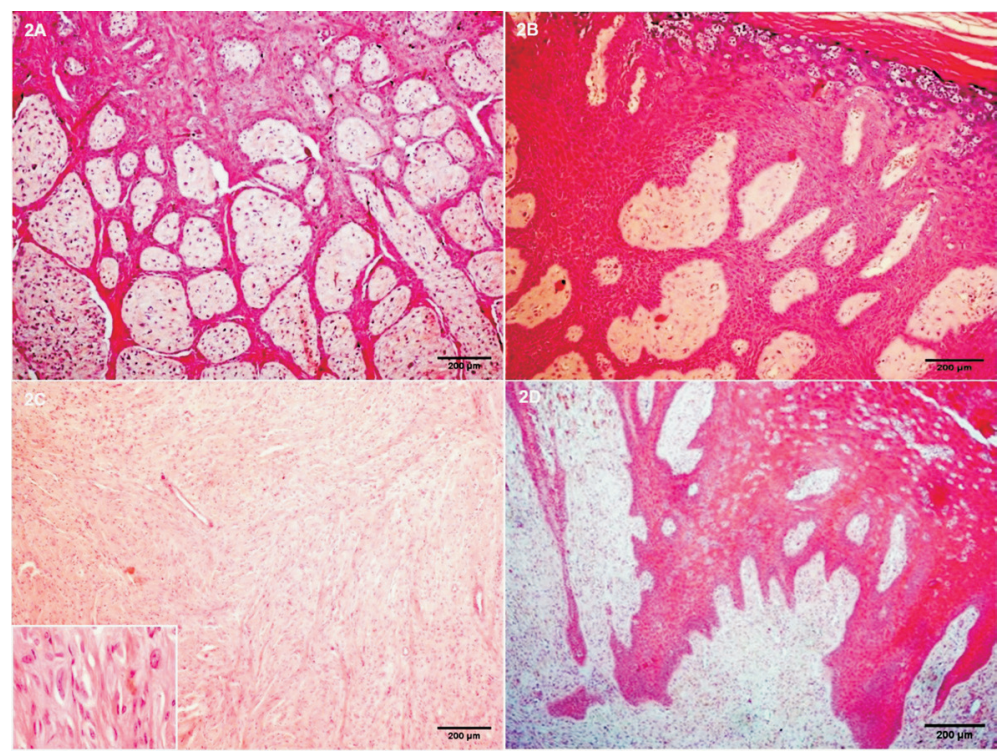

Fig. 2A - Cutaneous wart showing fibrous tissue islands between proliferating neoplastic keratinocytes with variable length but elongated rete pegs penetrating the prominent dermal fibrous tissue. Fibropapilloma, H\&E; $\times 100$.

Fig. 2B - Marked acanthotic stratum spinosum and basophilic keratohyaline granules. Fibropapilloma, H\&E; $\times 100$.

Fig. 2C - Excessive proliferation of fibrous connective tissue with the presence of fibrocytes and fibroblasts of

variable sizes containing pleomorphic nuclei (inset) and arranged in different directions. Fibrosarcoma, H\&E;

$\times 100$. Fig. 2D - Teat wart showing marked acanthosis of the stratum spinosum with numerous koilocytes and welldeveloped rete pegs. Fibropapilloma, H\&E; $\times 100$. 


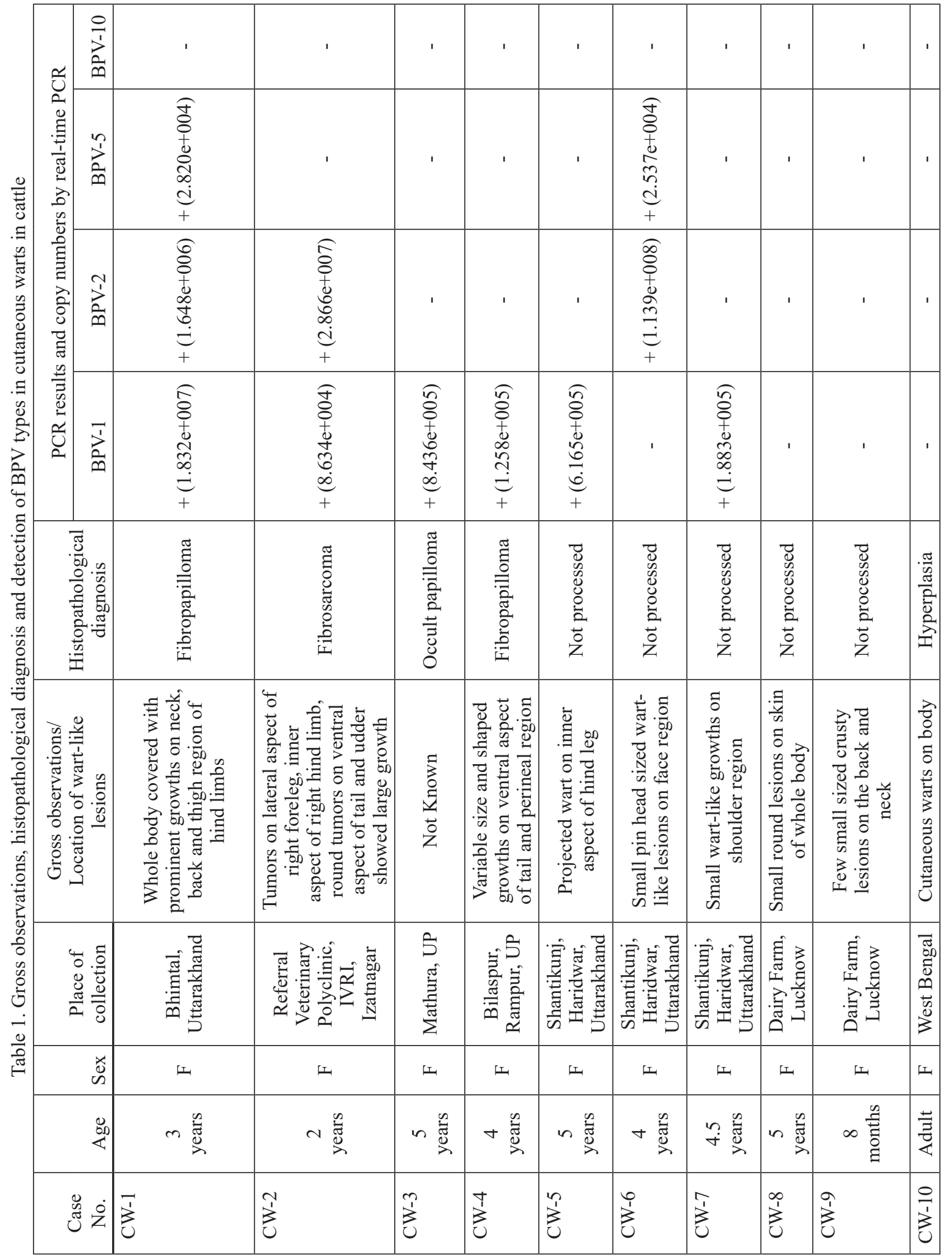




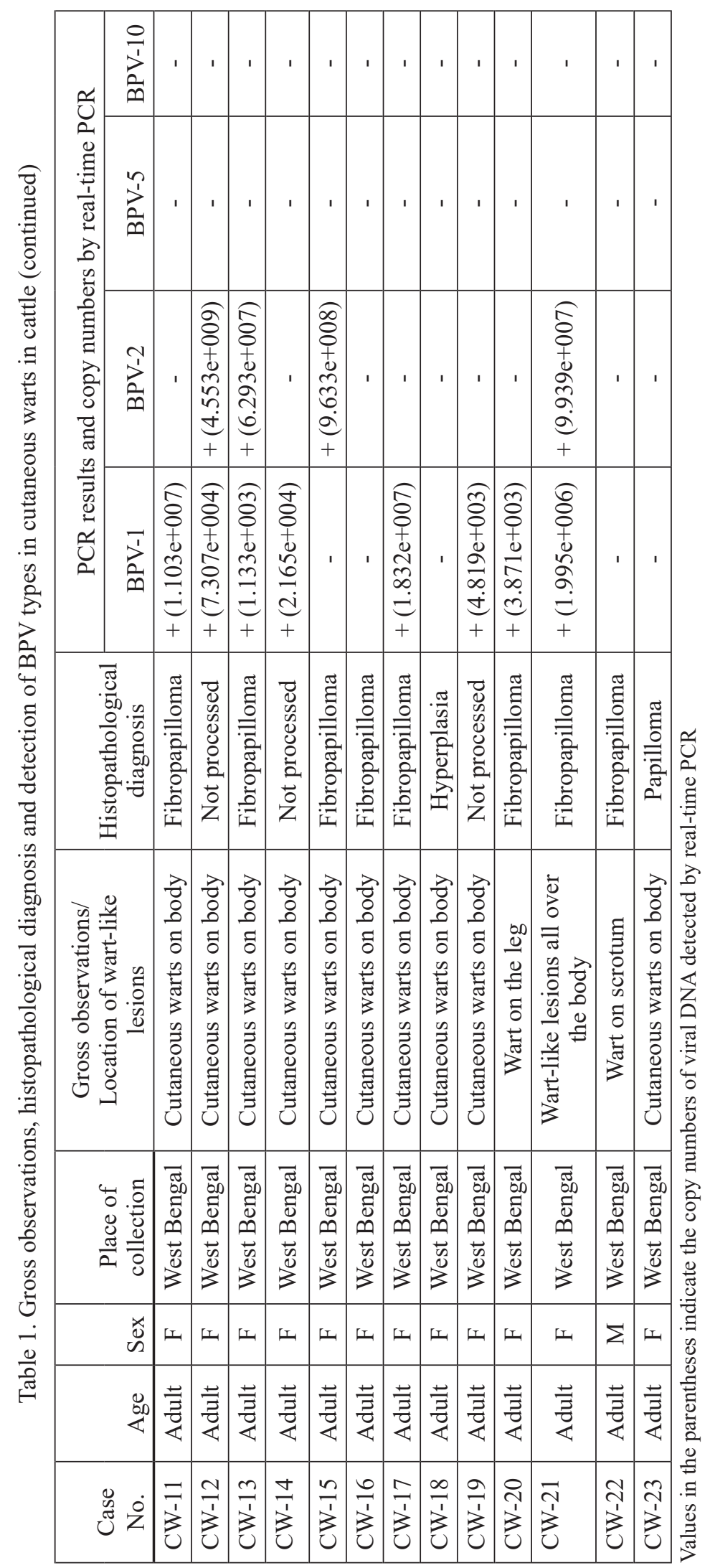




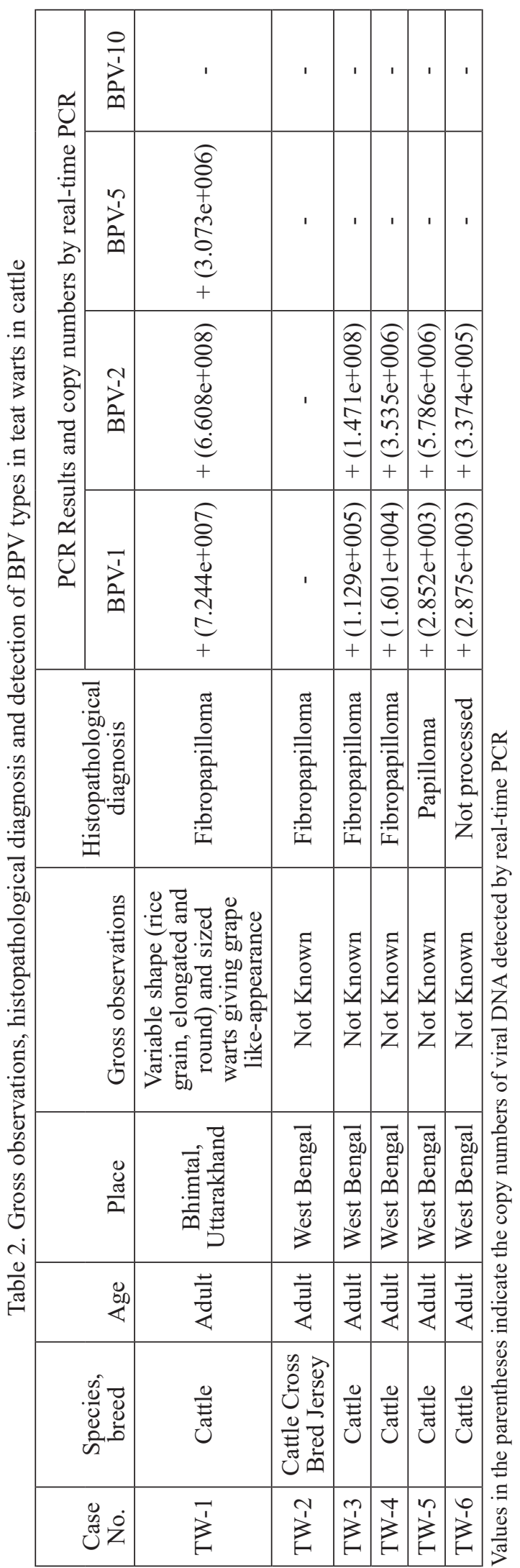

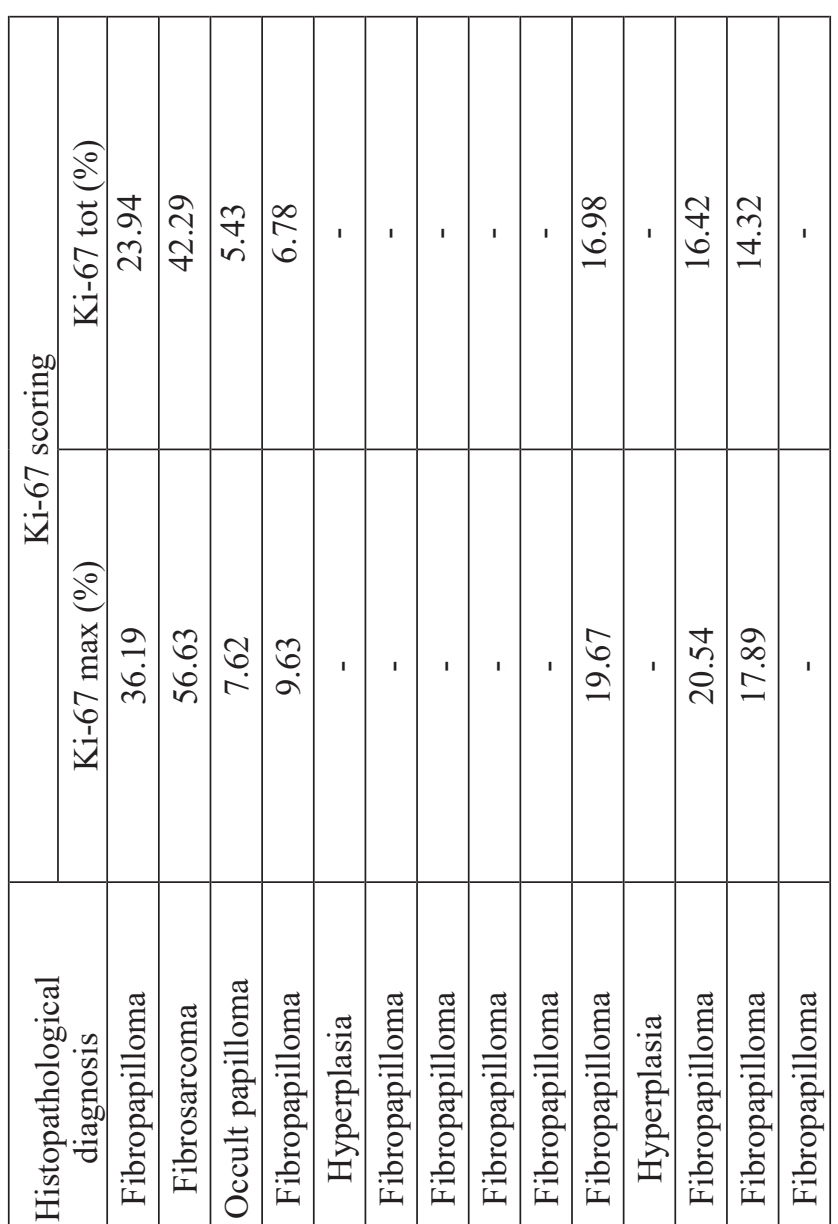

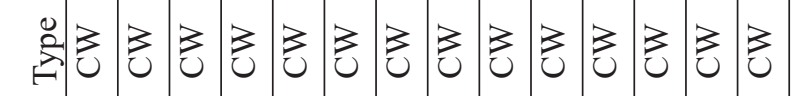
0
0
0 


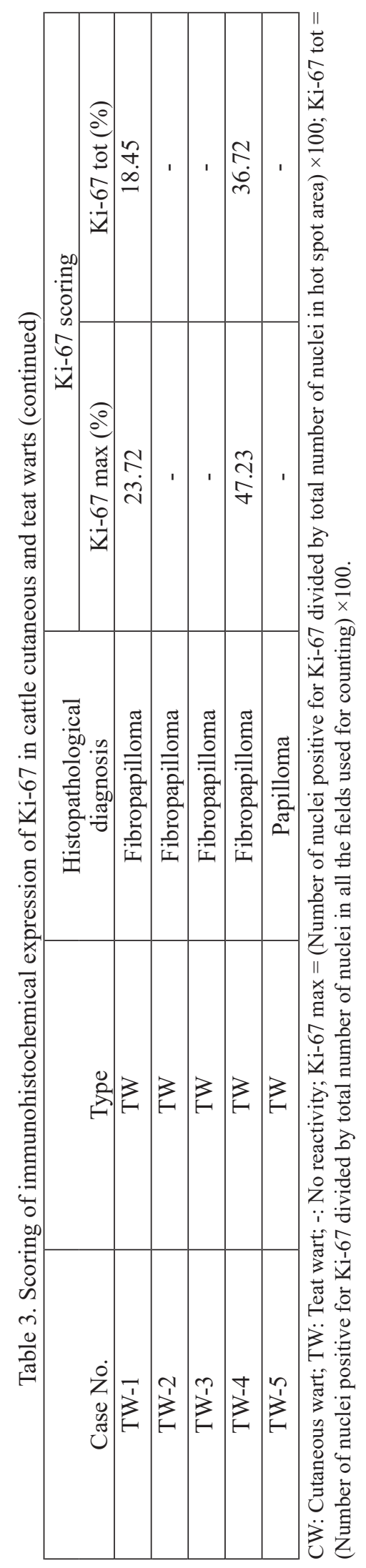

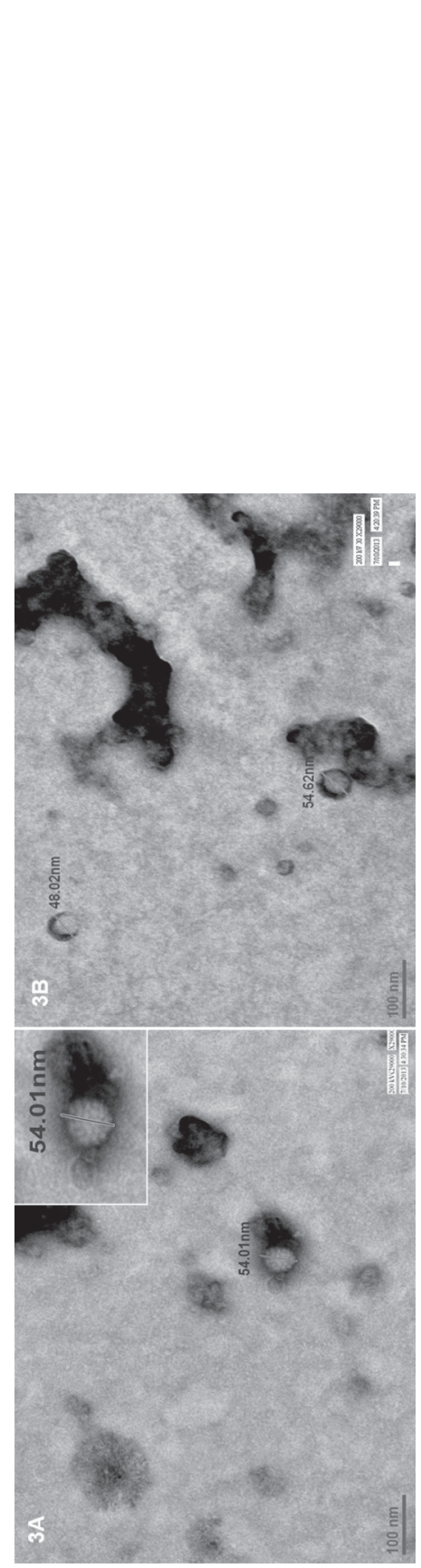

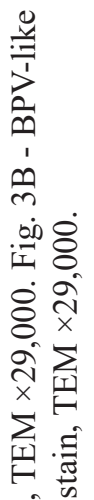

产要

喾

ح

党营

ㄷํㅇ

$3-$

के चे

牙

कs

.

:

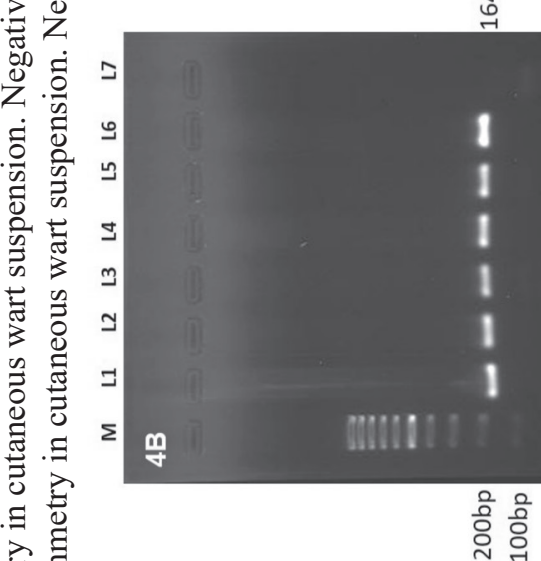

고

$\exists$ 当

च छे

言

를

ㅎ․ㄹ

至

$\sum$ 吾

我

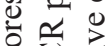

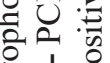

क

于

ه

州客章

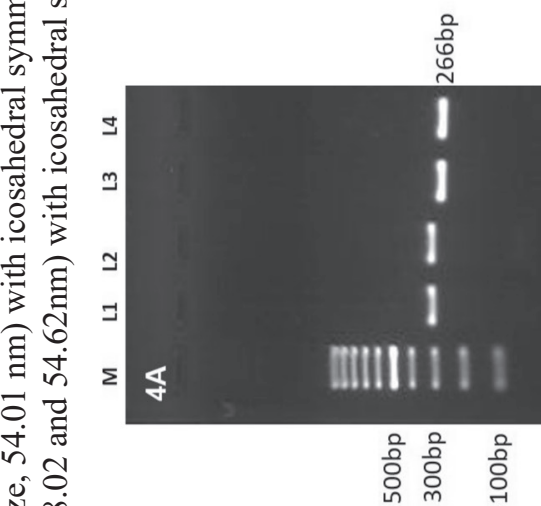

त

की

究定

$\circ \cdots$

?

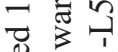

$\exists$

颉

莳薄

를

空

春

.

(

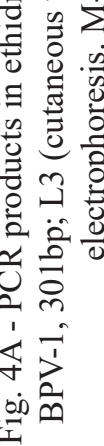




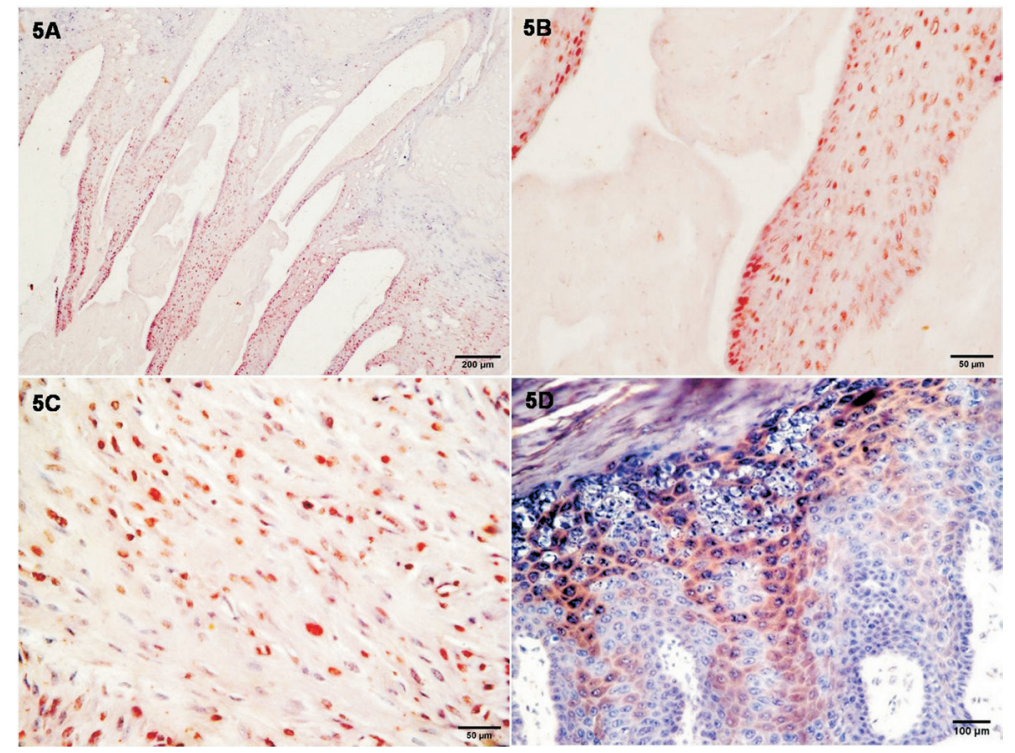

Fig. 5A - Strong Ki-67 immunostaining in stratum basal and spinosum layers in fibropapilloma. IHC; $\times 100$.

Fig. 5B - Higher magnification of Fig. 5A showing intense immunopositivity for Ki-67 in stratum basal and spinosum layers. IHC; $\times 400$. Fig. $5 \mathrm{C}$ - Proliferating fibroblasts with intense nuclear immunostaining for Ki-67 in fibrosarcoma. IHC $\times 400$. Fig. 5D Fibropapilloma showing moderate intracytoplasmic COX-2 immunostaining in stratum spinosum (mainly) and granulosum (occasionally). IHC; $\times 200$.

PCR results revealed that BPV-1 was detected in 9 cases of cattle CWs, BPV-2 in 1 case and mixed infections of BPV-1, and -2 in 4 cases. Mixed infections of BPV-2 and -5; BPV-1, -2 and -5 were detected in one case each. A total of 7 samples were negative for the DNA of BPV-1, -2 and -5 . Out of 6 TW samples, 4 were positive for mixed infections of BPV-1 and -2, 1 for BPV-1, -2 and -5, while one was negative for the presence of DNA of BPV-1, -2 and -5 . All the samples of CWs and TWs were negative for BPV-10. The specific PCR product size of 301, 164 and 266 bp for BPV-1, -2 and -5, respectively (Figs. 4A, 4B) were visualized on gel electrophoresis. GenBank Accession Numbers assigned to sequences generated in the present study were HG918265, KF055289, HG007968, HG007969, HG007970, KF114853, KF148687 and KF055287.

Real-time PCR. In the present study, DNA samples of CWs showed copy numbers $/ \mu \mathrm{L}$ of BPV$1,-2,-5$ ranging from $1.133 \mathrm{e}+003$ to $1.832 \mathrm{e}+007$, $1.648 \mathrm{e}+006$ to $4.553 \mathrm{e}+009$ and $2.537 \mathrm{e}+004$ to $2.820 \mathrm{e}+004$, respectively. The TWs samples positive for BPV-1, -2 and -5 had copy numbers ranging from $2.852 \mathrm{e}+003$ to $7.244 \mathrm{e}+007,3.374 \mathrm{e}+005$ to $6.608 \mathrm{e}+008$ and $3.073 \mathrm{e}+006$, respectively.

Immunohistochemistry A total of 19 samples (14 CWs and 5 TWs) were studied for expression of Ki-67 and COX-2 by immunohistochemistry. In one case, the tissue section was lost repeatedly during antigen retrieval so it was not processed for immunohistochemistry; however, this was performed in all the cases that were subjected for the histopathological examination.

Ki-67 expression. A total of 7/14 (50\%) CWs were positive for Ki-67 immunostaining. The detailed results are presented in Table 3.

The immunostaining was restricted mainly to the basal and supra basal layers in fibropapilloma cases. Only a few discrete cells of the basal layer showed immunopositivity for Ki-67. In one case, pronounced immunostaining was observed in the cells of the stratum basal and stratum spinosum (Figs. 5A, 5B). A few cells in the stratum granulosum layer and fibrous stroma also showed a positive reaction. In another case, strong immunostaining for Ki-67 was observed in the stratum spinosum and granulosum. One case of occult papilloma 
was positive for Ki-67 and the immunoreactivity was restricted to only fibrous connective tissue. The reactivity for Ki-67 was mainly restricted to the nuclei only. Immunoreactivity for Ki-67 with intense nuclear staining was observed in the fibrosarcoma case (Fig. 5C). Immunostaining for Ki-67 was observed in 2/5 (40\%) TW cases. These revealed a pattern of immunostaining similar to that of CWs.

\section{Discussion}

This study was conducted to investigate the pathology and the involvement of different types of BPVs in cattle CWs and TWs. The tumors (either benign or malignant) caused by BPV are important diseases across the world in beef and dairy cattle. The gross observations in CWs in this study were similar to those described by KUMAR et al. (2013b). This indicates that it is a common ailment in the country. A few cases of TWs in the present study were mostly rice grain-like, but some were sessile, small elevated grayish growths, usually multiple in numbers. These findings are in corroboration with those of earlier authors (SINGH and SOMVANSHI, 2010; KUMAR et al., 2013a). TWs seem to be an emerging problem in cows and they cause difficulty in milking and cause injuries which may lead to mastitis, and ultimately to loss in milk production and significant economic losses to farmers. A cow (Case No. CW-1 and TW-1) from a hilly area, had numerous growths on its body as well as the teats. Some of the growths on the teats had coalesced together to form grape-like clusters, while a few other growths had pointed tips and broad bases projecting out from the surface. The animal was pregnant, had heavy tick infestation and was allowed to go to graze in fern infested areas. PCR also detected the presence of DNA of BPV$1,-2$ and -5 . The extensive papillomatosis and the severity of the infection in this case may be due to immunosuppressive changes as a result of multiple factors such as stress caused by pregnancy, heavy tick infestation, a mixed infection of different BPV types, and also probably due to the some of the co-factors present in plants and the grasses of the hilly tract that had been consumed by animal
COX-2 expression. Only 3 of 19 (15.78\%) samples showed immunoreactivity for COX-2. These included 2 cases of CWs (fibropapilloma) and 1 TW (fibropapilloma). Immunostaining for COX2 was observed in the cytoplasm and cell membrane of suprabasal cells, mainly in the stratum spinosum (Fig. 5D). The staining intensity was categorized as mild to moderate.

over a long period of time. MUNDAY (2014) also reported that the immunosuppression predisposes to papilloma virus infection and can lead to extensive and persistent papilloma formation. Our group also observed a similar type in two more cases in which the body/face of the animal was covered with extensive papillomatous growths (SOMVANSHI and SHARMA, 1996; PATHANIA et al., 2010). Similar to the present case, these animals were also pregnant and lived in a hilly tract where bracken fern grows in abundance. In both cases, the animals completely recovered within 2-3 months after calving with complete regression of the warts. In another hill heifer calf, approximately 75 per cent of the animal's body was covered with extensive papillomatous growths. It was treated with the homeopathy medicine thuja 30 and later recovered completely. In such cases, it seems that extensive immunosuppression occurred due to exposure to bracken fern or some other factors which resulted in the proliferation of extensive growths in a specific region or over the whole body. Once it is removed, the growths completely regress and the animal has a healthy life.

On histopathological examination, these warts were diagnosed as fibropapilloma, papilloma and hyperplasia. The most common type was fibropapilloma in both cutaneous and teat warts. Histopathological findings and the presence of the DNA of either BPV-1 or BPV-2 or their coinfections by PCR in cattle CWs was in agreement with earlier reports by Indian authors (PANGTY et al., 2010; KUMAR et al., 2013b). This indicates that BPV-1 and -2 are prevalent in the Indian cattle population. However, to the best of the author's 
knowledge, BPV-5 DNA was detected in CWs in India for the first time in two cases as co-infection with BPV-1 and -2. However, infection with BPV-5 has been reported by earlier authors in cattle facial skin papilloma and cutaneous fibropapillomas (BLOCH et al., 1994; JELINEK and TACHEZY, 2005). BPV-1, -2, -6 and -8 co-infections have been reported in cattle CWs from Southern Brazil (CLAUS et al., 2009). The presence of ten different BPV types, with the exception of BPV-7, have been reported in skin lesions in Brazilian cattle herds (CARVALHO et al., 2012). The presence of either BPV-1 or BPV-10 alone or their co-infections in TWs has been reported by earlier authors from India (KUMAR et al., 2013a). However, BPV5 DNA was detected in TWs in India for the first time. BPV-5 DNA was detected in one case as coinfection with BPV-1 and -2. Detection of BPV-5 in TWs in the present study is in agreement with OGAWA et al. (2004) who detected BPV-1, -3, -5 and -6 in bovine teat papillomas and healthy cattle teat skin from Japanese herds. However, DNA of BPV-5 either alone or mixed infection with BPV-1 and -2 have been reported in mucosal warts from India (KUMAR et al., 2015). All the samples of CWs and TWs were negative for BPV-10. This is contrary to earlier authors who reported the presence of BPV-10 DNA in CWs (CARVALHO et al., 2012) and TWs (CARVALHO et al., 2012; KUMAR et al., 2013a).

In the present study, DNA samples of CWs of the cattle revealed varied copy numbers of the viral DNA. The highest copy numbers of BPV-1 and -5 were detected in TW, while the same was true for BPV-2 in CWs. These findings are in agreement with earlier authors (KUMAR et al., 2013a; KUMAR et al., 2013b; BAM et al., 2013). The information on quantification of BPV-5 in the TWs is not available but it was quite evident that the copy numbers of these are variable among the different samples, and varied from low to moderate.

Immunohistochemical expression patterns of the Ki-67 in the present study were similar to earlier studies in human and cattle papillomatosis by different authors (LU et al., 1999; OZSOY et al., 2011; KUMAR et al., 2013b). Immunostaining was restricted mainly to the suprabasal layers, mostly in the spinosum layer, however discrete immunoreactivity for Ki-67 was observed in basal layer. In fibropapilloma/ papilloma cases, Ki-67 immunoreactivity in supra basal cells mainly in the spinosum layer indicated these as the sites of cellular proliferation. Immunostaining for COX-2 was observed in the cytoplasm and cell membrane of suprabasal cells mainly in the stratum spinosum. The staining intensity was categorized as only mild. Since the tumors were benign in nature, COX-2 expression was observed in only a few cases which is in corroboration with earlier authors (BALAN et al., 2011; LEE et al., 2012). BALAN et al. (2011) investigated COX-2 immuno-expression in low and high-grade cervical squamous intraepithelial lesions and reported that COX-2 levels were increased as the squamous lesions progressed. Similarly, LEE et al. (2012) studied the pattern of COX-2 expression in the malignant transformation of sinonasal inverted papilloma. The percentage of COX-2 positive immunostaining was significantly higher in inverted papilloma with squamous cell carcinoma (SCC) and primary SCC, as compared with benign inverted papillomas.

\section{Conclusion}

In conclusion, the co-infection of two or three different viral types in cattle CW and TW cases demonstrated the diversity of the BPV types involved in these conditions. CWs and TWs in cattle are more frequently associated with BPV$1 /-2$ and their mixed infections in India, with the rare presence of BPV-5. Thus, while considering immunization strategies, multiple infections cause implications as vaccine introduction against a single BPV type may not protect the animals from other genotypes which may produce such cutaneous lesions. Further studies are required to discover the associations of other BPV types in India, as these are also prevalent in other parts of the world.

\section{Conflict of interest}

The authors declare that they have no conflicts of interest. 
B. L. Jangir and R. Somvanshi: Pathological studies and detection of co-infection of bovine papilloma viruses in cattle cutaneous and teat warts

\section{Acknowledgements}

The Director of ICAR-Indian Veterinary Research Institute, Izatnagar, is gratefully acknowledged by the authors for providing the necessary facilities for conducting the study. The first author is grateful to the Indian Council of Agricultural Research, New Delhi, for providing a scholarship during the course of the study.

\section{References}

BALAN, R., C. AMALINEI, S. E. GIUSCA, D. DITESCU, V. GHEORGHITA, E. CRAUCIUC, I. D. CARUNTU (2011): Immunohistochemical evaluation of COX-2 expression in HPV positive cervical squamous intraepithelial lesions. Rom. J. Morphol. Embryol. 52, 39-43.

BAM, J., P. KUMAR, G. D. LEISHANGTHEM, A. SAIKIA, R. SOMVANSHI (2013): Spontaneous cutaneous papillomatosis in yaks and detection and quantification of bovine papillomavirus-1 and -2. Transbound. Emerg. Dis. 60, 475-480.

DOI: 10.1111/j.1865-1682.2012. 01361.x

BLOCH, N., R. H. SUTTON, P. B. SPRADBROW (1994): Bovine cutaneous papillomas associated with bovine papillomavirus type 5. Arch. Virol. 138, 373-377. DOI: 10.1007/bf01379140

CAMPO, M. S. (2006): Bovine papilloma virus: old system, new lessons. In: Papilloma Virus Research: From Natural History to Vaccine and Beyond. (Campo, M. S., Ed.), Wymondham, Caister Academic Press.

CARVALHO C. C. R., M. V. A. Batista, M. A. R. Silva, V. Q. BALBINO, A. C. FREITAS (2012): Detection of bovine papillomavirus types, co-infection and a putative new BPV 11 subtype in cattle. Transbound. Emerg. Dis. 59, 441-447. DOI: $10.1111 / \mathrm{j} .1865-1682.2011 .01296 . \mathrm{x}$

Claus, M. P., M. LUNARDI, A. A. ALFIERI, R. A. A. OTONEL, D. SARTORI, M. H. P. FUNGARO, A. F. ALFIERI (2009): Multiple bovine papillomavirus infections associated with cutaneous papillomatosis in Brazilian cattle herds. Braz. Arch. Biol. Technol. 52, 93-98. DOI: org/10.1590/S1516-89132009000700013

DOORBAR, J., W. QUINT, L. BANKS, I. G. BRAVO, M. STOLER, T. R. BROKER, M. A. STANLEY (2012): The biology and life-cycle of human papillomaviruses. Vaccine. 30S5, F55-F70.

DOI: $10.1016 /$ j.vaccine.2012.06.083

DORE, M., I. LANTHIER, J. SIROIS (2003): Cyclooxygenase-2 expression in canine mammary tumors. Vet. Pathol. 40, 207-212.

DOI: $10.1354 /$ vp.40-2-207

HOWLEY, P. M., J. T. SCHILLLER, D. R. LOWY (2013): Papillomaviruses. In: Fields Virology. (Knipe, D. M., P. M. Howley, Eds.), Lippincott Williams and Wilkins, pp. 1662-1703.

JELINEK F., R. TACHEZY (2005): Cutaneous papillomatosis in cattle. J. Comp. Path. 132, 70-81.

DOI: $10.1016 /$ j.jcpa.2004.07.001
JUBB, K. V. F., P. C. KENNEDY, N. C. PALMER (2016): Pathology of domestic animals. $6^{\text {th }}$ ed., Elsevier, St. Louis, Missouri.

KUMAR, P., B. L. JANGIR, G. SAIKUMAR, R. SOMVANSHI (2013a): Co-infection of bovine papillomavirus type-1 and -10 in teat warts of dairy cattle. Vet. Med. 58, 605-608.

KUMAR, P., N. NAGARAJAN, D. KUMAR, R. B. BIND, R. SOMVANSHI (2013b): Detection and quantification of bovine papillomaviruses (BPVs) in cutaneous warts of cattle and buffaloes. Adv. Anim. Vet. Sci. 1, 53-58.

KUMAR, P., N. NAGARAJAN, G. SAIKUMAR, R. S. ARYA, R. SOMVANSHI (2015): Detection of bovine papilloma viruses in wart like lesions of upper gastrointestinal tract of cattle and buffaloes. Transbound. Emerg. Dis. 62, 264-271. DOI: $10.1111 /$ tbed.12127

LANCASTER, W. D., C. OLSON (1978): Demonstration of two distinct classes of bovine papillomavirus. Virology. 89, 372-379.

DOI: 10.1016/0042-6822(78)90179-4

LEE, G. H., Y. H. YOON, Y. M. KIM, M. K. YEO, Z. L. LIANG, J. M. KIM, K. S. RHA (2012) Pattern of expression of cyclooxygenase-2 in malignant transformation of sinonasal inverted papilloma. Am. J. Otolaryngol. 33, 585-589. DOI: 10.1016/j.amjoto.2012.03.003

LU, S., J. TIEKSO, S. HIETANEN, K. SYRJAENEN, V. K. HAVU, S. SYRJAENEN (1999): Expression of cell-cycle proteins p53, p21 (WAF-1), PCNA and Ki-67 in benign, premalignant and malignant skin lesions with implicated HPV involvement. Acta Derm. Venereol. 79, 268-273.

DOI: $10.1080 / 000155599750010634$

LUNA, L. G. (1968): Manual of histological staining methods of the Armed Force Institute of Pathology. $3^{\text {rd }}$ ed. Mc GrawHill Book Co, London.

MUNDAY, J. S. (2014): Bovine and human papillomaviruses: a comparative review. Vet. Pathol. 51, 1063-1075. DOI: $10.1177 / 0300985814537837$

OGAWA, T., Y. TOMITA, M. OKADA, K. SHINOZAKI, H. KUBONOYA, I. KAIHO, H. SHIRASAWA (2004): Broad-spectrum detection of papillomaviruses in bovine teat papillomas and healthy teat skin. J. Gen. Virol. 85, 2191-2197.

DOI: 10.1099/vir.0.80086-0

OZSOY, S. Y., Z. OZYILDIZ, M. GUZEL (2011): Clinical, pathological and immunohistochemical findings of bovine cutaneous papillomatosis. Ankara Univ. Vet. Fak. 58, 161165.

PANGTY, K., S. SINGH, R. GOSWAMI, G. SAIKUMAR, R. SOMVANSHI (2010): Detection of BPV-1 and -2 and quantification of BPV-1 by real-time PCR in cutaneous warts in cattle and buffaloes. Transbound. Emerg. Dis. 57, 185-196.

DOI: 10.1111/j.1865-1682.2009. 01096.x 
B. L. Jangir and R. Somvanshi: Pathological studies and detection of co-infection of bovine papilloma viruses in cattle cutaneous and teat warts

PATHANIA S., P. KUMAR, P. K. JOSHI, D. KUMAR, R. SOMVANSHI (2010): Extensive persistent cutaneous papillomatosis in a hill cow. Abstracts cum souvenir of national seminar on advances in animal cancer research in India: Diagnosis, treatment and clinical management. (Dhama, K., R. Somvanshi, Eds.), Division of Pathology, Indian Veterinary Research Institute, Izatnagar, Uttar Pradesh, India, p. 66.

RUSSO, V., F. ROPERTO, D. de BIASE, P. CERINO, C. URRARO, J. S. MUNDAY, S. ROPERTO (2020): Bovine papillomavirus type 2 infection associated with papillomatosis of the amniotic membrane in water buffaloes (Bubalus bubalis). Pathogens 9, 262.

DOI: $10.3390 /$ pathogens 9040262

SCHMITT, M., V. FIEDLER, M. MULLER (2010): Prevalence of BPV genotypes in a German cowshed determined by a novel multiplex BPV genotyping assay. J. Virol. Methods. 170, 67-72.

DOI: $10.1016 /$ j.jviromet.2010.08.020
SILVA M. S., M. WEISS, M. C. S. BRUM, B. L. DOS ANJOS, F. D. TORRES, R. WEIBLEN, E. F. FLORES (2010): Molecular identification of bovine papillomaviruses associated with cutaneous warts in southern Brazil. J. Vet. Diagn. Investing. 22, 603-606.

DOI: $10.1177 / 104063871002200417$

SINGH, V., R. SOMVANSHI (2010): Spontaneous teat papillomatosis in Indian cows: a pathological study. Indian J. Vet. Pathol. 34, 5-8.

SOMVANSHI, R., R. D. SHARMA (1996): Therapeutic management of cutaneous warts in a heifer by thuja. Indian Vet. Med. J. 20, 234-235.

YAGUIU, A., C. DE CARVALHO, A. C. DE FREITAS, L. G. B. GOES, M. L. Z. DAGLI, E. H. BIRGEL Jr., W. BECAK, R. C. STOCCO dos SANTOS (2006): Papillomatosis in cattle: in situ detection of bovine papillomavirus DNA sequences in reproductive tissues. Braz. J. Morphol. Sci. $23,525-529$.

Received: 30 April 2020

Accepted: 25 September 2020

\section{JANGIR, B. L., R. SOMVANSHI: Istraživanje patologije i dokaz koinfekcije goveđim papiloma virusima na koži i bradavicama sisa goveda. Vet. arhiv 91, 589-602, 2021.}

\section{SAŽETAK}

Papilomi su benigni tumori kožnog i sluzničnog epitela koji se u goveda često nalaze. Proizvodni gubici i utjecaj na ekonomičnost uzgoja ovise o lokaciji i stupnju infekcije. Ovo je istraživanje provedeno kako bi se ustanovila patologija i povezanost različitih tipova goveđih papilomavirusa (BPV) na koži i bradavicama sisa goveda. Bradavice su većinom bile različite veličine i oblika (oblika zrna riže, cvjetače i rožnate izrasline nalik na prste ili nepravilna oblika). Histopatološki su bradavice dijagnosticirane kao fibropapilomi, papilomi, fibrosarkomi i hiperplazije. Fibropapilomi su bili najčešći histološki tip, obilježeni hiperkeratozom, parakeratozom i akantozom. PCR-om je dokazan DNA virusa BPV-1, BPV-2 i BPV-5 DNA ili koinfekcije tim virusima. Negativno bojenje elektronskom transmisijskom mikroskopijom pokazalo je čestice nalik na BPV. PCR-om u stvarnom vremenu otkriveni su različiti brojevi kopija virusne DNA virusa BPV-1, BPV-2 i BPV-5. Imunohistokemijskim je pretragama pronađena ekspresija Ki-67, većinom u proliferativnim stanicama stratum spinosum i nekoliko bazalnih stanica u papilomima i fibropapilomima. Provedeno je imunobojenje ciklooksigenazom 2 u citoplazmi i staničnoj membrani suprabazalnih stanica. Zaključeno je da su u Indiji bradavice na koži i sisama u goveda mnogo češće povezane s BPV-1 i BPV-2 i mješovitim infekcijama tim virusima, dok je prisutnost virusa BPV-5 rijetka. DNA virusa BPV-5 prvi je put pronađena u bradavicama $u$ Indiji. Koinfekcije dvama ili trima različitim virusnim tipovima pokazuje raznolikost tipova BPV-a koji se nalaze u bradavicama. Učestala ekspresija Ki-67 u suprabazalnim slojevima može upućivati na njegovu povezanost s virusnom replikacijom i mjestima proliferacije.

Ključne riječi: goveđi papilomavirus; govedo; kožne bradavice; Ki-67; bradavice sisa 